\title{
HUBUNGAN KEPADATAN HUNIAN DAN KUALITAS FISIK RUMAH DESA PENDA ASAM BARITO SELATAN
}

\author{
Darmiah, Imam Santoso, Maharso \\ Poltekkes Kemenkes Banjarmasin Jurusan kesehatan Lingkungan Banjarbaru \\ e-mail: darmiah0708@gmail.com
}

\begin{abstract}
Residential density and housis physical quality in the Penda Asam Village of district South Barito 2014. A house that doesn't meet the physical requirements can cause immune deficiencies so that the diseases so easily affected. This research aims to know the physical quality's house and residential density in the Penda Asam's village of South hamlet subdistrict South Barito regency 2014. This research design was cross sectional with observation method, and measurement. The research population is 195 head of family with 51 houses sample. Data analysis was based on Kepmenkes RI No.829/Menkes/SK/VII/1999 about health housing requirements. The research result showed physical quality's house: the kind of zinc roof as many as 35 houses $68,6 \%$ and $11,8 \%$ multiroof. The lighting eligible as $74,5 \%$; ineligible as $25,5 \%$, the temperature eligible as $7,8 \%$; ineligible as $92,2 \%$, the humidity eligible as $17,6 \%$; ineligible as $82,4 \%$, the residential density not solid's category as $45 \%$; solid's category as $55 \%$. The effort to overcome the problem: open the window in the morning, keep the ventilation system so that air circulation can be fluently, do reforestation around the house so that the environment condition becomes cool.
\end{abstract}

Keywords : Residential Density, House Physical (the kind of roof; lighting; temperature; humidity)

Abstrak: Hubungan kepadatan hunian dan Kualitas Fisik Rumah Desa Penda Asam Barito Selatan Tahun 2014. Rumah yang tidak memenuhi persyaratan fisik dapat menyebabkan menurunnya daya tahan tubuh sehingga mudah terkena penyakit. Penelitian bertujuan mengetahui kualitas fisik rumah dan kepadatan hunian di Desa Penda Asam Kabupaten Barito Selatan Tahun 2014. Desain penelitian cross sectional, metode penelitian wawancara, dan pengukuran. Populasi penelitian 195 Kepala Keluarga (KK), sampel sebanyak 51 rumah. Analisis data berpedoman pada Kepmenkes RI Nomor 829/Menkes/ SK/VII/1999 tentang Persyaratan Kesehatan Perumahan. Hasil penelitian menunjukkan kualitas fisik rumah: 68,6\%, jenis atap seng, dan $11,8 \%$ multiroof. Pencahayaan memenuhi syarat $74,5 \%$; tidak memenuhi syarat $25,5 \%$, suhu memenuhi syarat $7,8 \%$; tidak memenuhi syarat $92,2 \%$, kelembaban memenuhi syarat $17,6 \%$; tidak memenuhi syarat $82,4 \%$; kepadatan hunian kategori tidak padat $45 \%$; kategori padat 55\%. Upaya mengatasi permasalahan: membuka jendela pada pagi hari, menjaga sistem ventilasi agar sirkulasi udara lancar, melakukan penghijauan disekitar rumah agar kondisi lingkungan menjadi sejuk.

Kata Kunci : Kepadatan Hunian; Kualitas Fisik Rumah(Jenis Atap; Pencahayaan; Suhu; Kelembaban). 


\section{PENDAHULUAN}

Masalah kesehatan merupakan masalah yang sangat kompleks berkaitan dengan masalah lain diluar kesehatan. Masalah kesehatan masyarakat tidak dapat berdiri sendiri melainkan harus melibatkan berbagai macam disiplin ilmu untuk menanggulanginya ${ }^{1}$.

Faktor terbesar yang mempengaruhi kesehatan adalah lingkungan. Kesehatan lingkungan pada hakikatnya adalah suatu kondisi yang optimum sehingga berpengaruh positif terhadap terwujudnya status kesehatan yang optimum pula. Ruang lingkup lingkungan yang paling dekat dengan kegiatan manusia adalah rumah, dimana rumah sebagai tempat tinggal dan tempat beraktifitas manusia. Rumah merupakan tempat dimana anggota keluarga berkumpul dan berhubungan juga sebagai tempat untuk mendapatkan kesenangan, kecintaan dan kebahagian. Oleh karena itu rumah harus memenuhi syarat-syarat kesehatan ${ }^{2}$.

Rumah yang tidak sehat erat kaitannya dengan peningkatan kejadian Infeksi Saluran Pernafasan Akut (ISPA) yang merupakan penyakit infeksi akut menyerang salah satu bagian atau lebih saluran nafas mulai dari hidung hingga alveoli termasuk jaringan disekitar hidung, rongga telinga tengah dan pleura ${ }^{3}$.

Rumah yang tidak memenuhi persyaratan, dapat mengakibatkan menurunnya daya tahan tubuh sehingga tubuh mudah terkena penyakit. Seperti yang dikemukakan WHO bahwa rumah yang terlalu sempit mengakibatkan tingginya kejadian penyakit dalam masyarakat.

Penelitian (Herlina, 2010) menyatakan ada hubungan antara kelembaban dan kepadatan hunian dengan kejadian ISPA Non Pnemonia pada balita di Kelurahan Tewah Kalimantan Tengah. Hasil uji statistik Chi-Square yaitu nilai p value sebesar $0,000<\alpha(0,05)$ dengan nilai $\mathrm{OR}=$ 8,179 maka balita yang kelembaban di ruang tidurnya tidak memenuhi syarat 40$70 \%$ akan beresiko terkena ISPA Non Pnemonia 8,179 kali lebih besar daripada balita yang kelembaban di ruang tidurnya memenuhi syarat dengan $\mathrm{CI}=(2,683-$ 24,939 ) serta hubungan kepadatan hunian dengan kejadian ISPA Non Pnemonia, hasil uji statistik Chi-Square yaitu nilai p value $=$ $0,000<\alpha(0,05)$ dengan nilai $\mathrm{OR}=17,333$ maka balita yang ruang tidurnya padat hunian akan beresiko terkena ISPA Non Pnemonia 17,333 kali lebih besar dibandingkan dengan balita yang ruang tidurnya tidak padat dengan $\mathrm{CI}=(5,154-$ 58,291).

Desa Penda Asam Selatan merupakan salah satu desa yang perlu mendapat perhatian dari segi permukiman. Pada tahun 2013 persentase rumah sehat di Desa Penda Asam 8 rumah (1,90 \%) termasuk kategori sehat dari 10 rumah yang diperiksa dengan jumlah keseluruhan 420 rumah.

Data Puskesmas Kalahien, desa Penda Asam pada kurun waktu 2 tahun terakhir ditemukan kasus ISPA tertinggi dengan urutan pertama dari 10 penyakit terbanyak. Pada tahun 2011 terdapat 1.961 kasus, pada tahun 2012 meningkat menjadi 2.175 kasus. Keadaan ini diperkirakan berkaitan erat dengan masalah perumahan sehat seperti luas ventilasi, pencahayaan, suhu, kelembaban dan kepadatan hunian, dilihat dari segi kesehatan keadaan ini berpengaruh besar pada tingginya insiden penyakit ISPA dan penyakit saluran pernafasan lainnya ${ }^{4}$

Berdasarkan uraian diatas, maka penelitian ini bertujuan untuk mengetahui kepadatan hunian dan kualitas fisik rumah di Desa Penda Asam Kabupaten Barito Selatan.

\section{METODE PENELITIAN}

Metode penelitian yang digunakan deskriftif, bertujuan untuk melihat gambaran kepadatan hunian dan kualitas fisik rumah dalam suatu populasi tertentu (4). Penelitian dilaksanakan di desa Penda Asam, dari April sampai dengan Juli 2014. Dengan populasi seluruh kepala keluarga sebanyak 195 KK. Sedangkan sampel penelitian sebanyak 51 sampel, ditentukan menggunakan rumus Lemeshow ${ }^{5}$ sebagai berikut : 


$$
\begin{aligned}
& \mathrm{n}=\frac{\mathrm{Z}_{1-\alpha / 2}^{2} \mathrm{P}(1-\mathrm{P}) \mathrm{N}}{\mathrm{d}^{2}(\mathrm{~N}-1)+\mathrm{Z}_{1-\alpha / 2}^{2} \mathrm{P}(1-\mathrm{P})} \\
& \mathrm{n}=\frac{131,18}{1,4222,61}=50,19 \approx 51 \text { sampel }
\end{aligned}
$$

Keterangan :

$$
\begin{aligned}
& \left.\mathrm{Z}_{1-\alpha / 2}^{2}=\text { derajat kemaknaan } 90 \% 1,64\right) \\
& \mathrm{P} \quad=\text { Proporsi } 50 \%(0,5) \\
& \mathrm{d} \quad=\quad \text { Derajat penyimpangan } \\
& 10 \%(0,1) \\
& \mathrm{N} \quad=\text { Jumlah populasi } \\
& \mathrm{n} \quad=\text { Besar sampel }
\end{aligned}
$$

Teknik pengambilan sampel secara simple random sampling 6 . Variabel penelitian adalah kepadatan hunian dan kondisi fisik rumah (jenis atap, pencahayaan, suhu, kelembaban). Data dikumpulkan menggunakan form observasi wawancara dan pengukuran. Pengukuran dilakukan pada siang hari. Data yang

Tabel 1. Jenis atap rumah responden desa Penda Asam diperoleh dinalisis secara deskriptif berpedoman pada Kepmenkes RI No.829/Menkes/SK/VII/1999 tentang Persyaratan Kesehatan Perumahan. Pencahayaan memenuhi syarat apabila $\geq 60$ lux, tidak memenuhi syarat $<60$ lux. Suhu memenuhi syarat antara $18^{\circ} \mathrm{C}-30^{\circ} \mathrm{C}$, tidak memenuhi syarat $<18^{\circ} \mathrm{C}$, dan $>30^{\circ} \mathrm{C}$. Kelembaban memenuhi syarat antara $40 \%$ $70 \%$, tidak memenuhi syarat $<40 \%$ dan $>70 \%$, kepadatan hunian padat apabila $>2$ orang dewasa $/ 8 \mathrm{~m}^{2}$, tidak padat $\leq 2$ orang dewasa/8m². Pengukuran pencahayaan, suhu dan kelembaban rumah responden dilakukan pada siang hari.

\section{HASIL DAN PEMBAHASAN}

\section{A. Hasil}

Berdasarkan form observasi yang digunakan kualitas fisik rumah di desa Penda Asam pada tahun 2014, dapat dilihat pada tabel berikut:

\begin{tabular}{lccc}
\hline \multirow{2}{*}{ No } & Jenis Atap & \multicolumn{2}{c}{ Hasil Pengamatan } \\
& & Jumlah rumah & $\%$ \\
\hline 1 & Multiroof & 6 & 11,8 \\
2 & Seng & 35 & 68,6 \\
3 & Sirap & 10 & 19,6 \\
\hline & Jumlah & 51 & 100 \\
\hline
\end{tabular}

Tabel 1 menunjukkan bahwa jenis atap rumah yang paling banyak digunakan atap seng, sebanyak 35 rumah $(86,6 \%)$ dan paling sedikit menggunakan atap multiroof yaitu 6 rumah (11,8\%). Seng merupakan salah satu dari sekian banyak bahan bangunan yang sering digunakan sebagai penutup atap. Penggunaan seng sebagai penutup atap tidak dianjurkan untuk bangunan utama, kecuali bangunan yang bersifat sederhana dan sementara. Hal ini disebabkan karena seng dapat menimbulkan suara yang gaduh serta tidak isolasi terhadap panas maupun dingin ${ }^{7}$. Bagi masyarakat dengan tingkat ekonomi menegah kebawah, seng merupakan alternatif yang tepat untuk digunakan karena harga relatif murah dan terjangkau. Faktor yang berpengaruh terhadap atap seng adalah suhu dan kelembaban, dan plafon. Plafon berfungsi sebagai insulator panas, karena dapat dapat menyerap panas matahari yang merambat melalui atap. Sirkulasi udara yang lancar dapat menciptakan suhu yang nyaman, agar sirkulasi udara dapat berfungsi maksimal maka harus diperhatikan tinggi plafon berkisar antara 2,4 hingga 3 meter dari lantai. 
Tabel 2. Pencahayaan rumah responden Desa Penda Asam

\begin{tabular}{cccc}
\hline No & \multirow{2}{*}{ Pencahayaan (Intensitas) } & \multicolumn{2}{c}{ Hasil Pengukuran } \\
& & Jumlah rumah & $\%$ \\
\hline 1 & $<60$ lux & 13 & 25,5 \\
2 & $\geq 60$ lux & 38 & 74,5 \\
\hline & Jumlah & 51 & 100 \\
\hline
\end{tabular}

Tabel 2 menunjukkan pencahayaan di rumah responden paling banyak $\geq 60$ lux yaitu 38 rumah $(74,5 \%)$ dan paling sedikit pencahayaan < 60 lux yaitu 13 rumah $(25,5 \%)$. Berdasarkan Kepmenkes RI 829/Menkes/SK/VII/1999 persyaratan minimal intensitas pencahayaan 60 lux dan tidak menyilaukan. Hasil Pengukuran intensitas pencahayaan rumah reponden sebagian besar sudah memenuhi syarat. Sebagian rumah yang tidak memenuhi syarat, disebabkan kebiasaan responden tidak membuka jendela dan keberadaan jendela yang terhalang oleh rumah atau bangunan lain, karena jarak rumah yang berdekatan, sehingga cahaya tidak dapat masuk langsung ke dalam rumah yang menyebabkan ruangan menjadi gelap. Untuk menambah penerangan dalam rumah dapat digunakan pencahayaan buatan misalnya menyalakan lampu, penggunaan fiber atau atap kaca ukuran $0,5 \mathrm{~m} \times 0,5 \mathrm{~m}$. Pencahayaan buatan yang baik dan memenuhi standar dapat dipengaruhi oleh cara pemasangan sumber cahaya pada dinding atau langit-langit, konstruksi sumber cahaya dalam ornament yang dipergunakan, luas dan bentuk ruangan serta penyebaran sinar dari sumber cahaya $^{8}$. Rumah yang sehat memerlukan cahaya yang cukup, tidak kurang dan tidak terlalu banyak. Kurangnya cahaya yang masuk ke dalam ruangan rumah, terutama cahaya matahari disamping kurang nyaman, juga merupakan media atau tempat yang baik untuk hidup dan berkembanganya bibit penyakit dalam rumah. Sebaliknya terlalu banyak cahaya dalam rumah akan menyebabkan silau dan akhirnya dapat merusak mata 4 .

Tabel 3. Suhu rumah responden desa Penda Asam

\begin{tabular}{cccc}
\hline \multirow{2}{*}{ No } & Suhu & \multicolumn{2}{c}{ Hasil Pengukuran } \\
& & Jumlah rumah & $\%$ \\
\hline 1 & $18{ }^{\circ} \mathrm{C}-30^{\circ} \mathrm{C}$ & 4 & 7,8 \\
2 & $<18{ }^{\circ} \mathrm{C}->30^{\circ} \mathrm{C}$ & 47 & 92,2 \\
\hline & Jumlah & 51 & 100 \\
\hline
\end{tabular}

Tabel 3 menunjukkan kondisi suhu rumah responden paling banyak 47 rumah $(92,2 \%)$ mempunyai suhu antara $<18{ }^{\circ} \mathrm{C}$ $>30{ }^{\circ} \mathrm{C}$ dan paling sedikit 4 rumah $(7,8 \%)$ suhu berkisar $18{ }^{\circ} \mathrm{C}-30 \stackrel{\circ}{\circ} \mathrm{C}$. Suhu udara yang dianjurkan agar ruangan menjadi nyaman berkisar 18-30 으. Banyaknya rumah dengan kondisi suhu tidak memenuhi syarat dikarenakan rumah tidak memiliki ventilasi sehingga menggangu sirkulasi udara yang menyebabkan ruangan menjadi pengap dan panas. Penghawaan (ventilasi) yang cukup menyebabkan hawa ruangan baik dan nyaman pada siang maupun malam hari. Ukuran ventilasi yang memenuhi syarat 10\%-20\% dari luas lantai. Ventilasi rumah selain bermanfaat untuk sirkulasi udara juga tempat masuknya sinar matahari serta dapat mempengaruhi kelembaban dalam ruangan ${ }^{9}$. 
Tabel 4. Kelembaban rumah responden desa Penda Asam

\begin{tabular}{cccc}
\hline \multirow{2}{*}{ No } & Kelembaban & \multicolumn{2}{c}{ Hasil Pengukuran } \\
& & Jumlah rumah & $\%$ \\
\hline 1 & $40 \%-70 \%$ & 9 & 17,6 \\
2 & $<40 \%->70 \%$ & 42 & 82,4 \\
\hline & Jumlah & 51 & 100 \\
\hline
\end{tabular}

Tabel 4 menunjukkan paling banyak rumah responden 42 rumah $(82,4 \%)$ kelembaban $<40 \%->70 \%$ dan paling sedikit 9 rumah $(17,6 \%)$. Ruang yang lembab dengan dinding yang basah akan sangat tidak nyaman dan dapat mengganggu kesehatan manusia. Banyaknya rumah dengan kondisi kelembaban yang tidak memenuhi syarat dikarenakan kebiasaan responden yang tidak membuka jendela terutama pada pagi hari serta lubang ventilasi yang terlalu kecil menyebabkan aliran udara di dalam ruangan tidak mengalir dengan lancar. Selain itu juga dapat disebabkan sinar matahari tidak dapat langsung masuk ke dalam rumah karena jarak antar rumah yang terlalu dekat sehingga cahaya yang masuk kerumah terhalang bangunan lainnya. Kelembaban ruangan yang tinggi akan menjadi media yang baik untuk tumbuh dan berkembang biaknya bakteribakteri pathogen. Untuk menjaga kualitas udara di dalam ruang kelembaban yang berasal dari dinding yang basah atau lantai yang lembab, harus dihindarkan ${ }^{10}$. Kelembaban dalam rumah, juga dapat dipengaruhi oleh jenis dan kondisi atap, karena pada saat turun hujan, titik-titik air hujan yang jatuh ke atap, sebagian kecil akan merembes melalui celah-celah atap. Air hujan tersebut akan meresap melalui dinding rumah sehingga menyebabkan dinding menjadi basah dan ruangan menjadi lembab. Kelembaban udara yang dianjurkan agar kualitas udara dalam ruang menjadi nyaman berkisar antara 40-70\% sesuai dengan Kepmenkes RI 829/Menkes/SK/VII/1999 tentang tentang Persyaratan Kesehatan Perumahan.

Tabel 5. Kepadatan hunian rumah responden desa Penda Asam

\begin{tabular}{cccc}
\hline \multirow{2}{*}{ No } & Kepadatan Hunian & \multicolumn{2}{c}{ Hasil Pengukuran } \\
\cline { 3 - 4 } 1 & & Jumlah rumah & $\%$ \\
2 & Padat & 28 & 55 \\
& Tidak Padat & 23 & 45 \\
\hline & Jumlah & 51 & 100 \\
\hline
\end{tabular}

Tabel 5 dapat menunjukkan kepadatan hunian rumah responden kategori padat 28 rumah $(55 \%)$ dan kategori tidak padat 23 rumah $(45 \%)$. Kepadatan hunian paling banyak termasuk kategori padat dan paling sedikit termasuk kategori tidak padat. Masih banyaknya rumah responden termasuk kategori padat dikarenakan luas rumah tidak mencukupi sesuai dengan persyaratan yaitu $8 \mathrm{~m} 2$ untuk 2 orang dewasa. Selain itu banyaknya jumlah anggota keluarga disebabkan karena masih ada dalam satu rumah ditempati oleh 2 (dua) KK. Kepadatan hunian (over crowding) menimbulkan efek negatif terhadap kesehatan fisik, mental maupun moral. Penyebaran penyakit menular di rumah yang padat penghuninya cepat terjadi8. Semakin banyak jumlah penghuni rumah maka semakin cepat udara ruangan mengalami pencemaran, sehingga kadar oksigen dalam ruangan menurun dan peningkatan $\mathrm{CO} 2$ yang menyebabkan penurunan kualitas udara dalam rumah ${ }^{11}$. 
Tabel 6. Analisis kepadatan hunian dan suhu rumah desa Penda Asam

\begin{tabular}{llccc}
\hline \multirow{2}{*}{ No } & Kepadatan Hunian & \multicolumn{2}{c}{ Suhu $\left({ }^{\circ} \mathrm{C}\right)$} & Total \\
& & 18 s.d 30 & $<18$ s.d $>30$ & \\
\hline 1. & Padat & $1(3,6 \%)$ & $27(52,9 \%)$ & 28 \\
2. & Tidak Padat & $3(13 \%)$ & $20(87 \%)$ & 23 \\
\hline & Jumlah & 4 & 47 & 51 \\
\hline
\end{tabular}

Tabel 6 menunjukkan bahwa pada rumah responden dengan kepadatan hunian kategori padat sebanyak 27 rumah $(52,9 \%)$ mempunyai suhu kurang dari $18^{\circ} \mathrm{C}$ dan lebih dari $30^{\circ} \mathrm{C}$. Berdasarkan Kepmenkes RI No.829/Menkes/SK/VII/1999 tentang Persyaratan Kesehatan Perumahan kondisi ini tidak memenuhi syarat. Dimana kepadatan hunian yang melebihi satandar dapat menyebabkan suhu ruangan meningkat akibat aktifitas penghuni rumah. Pada kondisi luas rumah yang cukup akan memberikan ruang gerak yang cukup dan memberikan perasaan yang nyaman bagi penghuninya. Kenyamanan dalam ruangan juga dapat terganggu karena sirkulasi udara yang tidak lancar, hal ini bisa disebabkan juga karena ventilasi yang kurang, sehingga menimbulkan suhu ruangan terasa panas. Untuk menjaga lancarnya sirkulasi udara dalam rumah, maka perlu diperhatikan sistem ventilasi rumah agar suhu ruangan selalu normal.

Tabel 7. Analisis kepadatan hunian dan kelembaban rumah desa Penda Asam

\begin{tabular}{|c|c|c|c|c|}
\hline \multirow[b]{2}{*}{ No } & \multirow[b]{2}{*}{$\begin{array}{l}\text { Kepadatan } \\
\text { Hunian }\end{array}$} & \multicolumn{2}{|c|}{ Kelembaban (\%) } & \multirow[t]{2}{*}{ Total } \\
\hline & & 40 s.d 70 & $<40$ s.d $>70$ & \\
\hline 1. & Padat & $0(0 \%)$ & $28(100 \%)$ & 28 \\
\hline 2. & Tidak Padat & $9(39,1 \%)$ & $14(60,9 \%)$ & 23 \\
\hline & Jumlah & 28 & 23 & 51 \\
\hline
\end{tabular}

Tabel 7 menunjukkan sebanyak 28 rumah (55\%) termasuk kategori padat dengan kelembabadarin kurang dari 40\% dan lebih $70 \%$. Kepadatan hunian didalam ruangan yang berlebihan akan berpengaruh pada kelembaban dalam ruangan. Luas rumah yang tidak sebanding dengan jumlah penghuninya akan menyebabkan overcrowded (jumlah penghuni rumah yang berlebihan). Hal ini menyebabkan kurangnya konsumsi oksigen, memudahkan terjadinya penularan penyakit. Kelembaban tinggi dapat disebabkan karena uap air dari keringat manusia maupun pernafasan. Kelembaban dalan ruang tertutup dimana banyak terdapat manusia di dalamnya lebih tinggi dibandingkan diluar ruangan. Hal ini membahayakan kesehatan karena mudahnya terjadi penularan penyakit.

\section{KESIMPULAN DAN SARAN}

Kesimpulan yang didapat dari penelitian ini adalah jumlah rumah responden yang menggunakan jenis atap seng sebanyak 35 rumah $(68,6 \%)$ jenis atap sirap sebanyak 10 rumah $(19,6 \%)$ dan jenis atap multiroof sebanyak 6 rumah $(11,8 \%)$. Pencahayaan dalam rumah respoden $74,5 \%$ memenuhi syarat berkisar antara 60-65 lux. Suhu rumah responden $92,2 \%$ tidak memenuhi syarat berkisar antara 31-35 ${ }^{\circ} \mathrm{C}$. Kelembaban dalam rumah responden $82,4 \%$ tidak memenuhi syarat berkisar antara 71-74 \%. Kepadatan hunian rumah responden 23 rumah (45\%) termasuk kategori padat dan 28 rumah (55\%) kategori tidak padat. Hasil penelitian ini dapat dijadikan sebagai bahan informasi bagi masyarakat dalam rangka menjaga kondisi lingkungan dalam rumah yang sehat perlu menjaga suhu dan kelembaban dalam 
rumah dengan tetap menjaga kelancaran sirkulasi udara dan pencahayaan yang masuk dalam rumah, memperhatikan ventilasi rumah tetap berfungsi sebagai tempat keluar masuk udara yang bersih.

\section{DAFTAR PUSTAKA}

1. Wardhana, Wisnu Arya. 2007. Dampak Pencemaran Lingkungan di Yogyakarta. Yogyakarta.

2. Entjang, Indan. 2000. Ilmu Kesehatan Masyarakat. PT. Citra Aditya Bakti. Bandung.

3. Depkes RI. 2009. Pedoman Pengendalian Penyakit Infeksi Saluran Pernafasan Akut. Jakarta.

4. Notoatmodjo, Soekidjo.2010. Metodologi Penelitian Kesehatan. Rineka Cipta: Jakarta.

5. Kasjono, Heru.S dan Yasril. 2009. Teknik Sampling untuk Penelitian Kesehatan. Graha Ilmu : Yogyakarta.

6. Marzuki dan Gunawan, 2002. Statistik Kesehatan .UGM. Yogjakarta.

7. Supribadi IK dalam Anwar, K. 1993. Ilmu Bangunan Gedung, seni Praktis Bangunan Sipil B. Armico. Bandung.

8. Istiqomah dan Hanas dalam Kasjono, ed. 2011. Penyehatan Pemukiman. Goysen Publishing: Yogyakarta.

9. Chandra, Budiman. 2006. Pengantar Kesehatan Lingkungan. EGC: Jakarta.

10. Pudjiastuti, L, dkk. 1998. Kualitas Udara dalam Ruang. Departemen Pendidikan dan Kebudayaan : Jakarta.

11. Lubis. 1989. Perumahan Sehat. Depkes RI. Jakarta. 